\title{
THE IMPACT OF TAXATION AS AN AID TO ECONOMIC DEVELOPMENT (APPLIED STUDY IN KURDISTAN REGIONAL GOVERNMENT)
}

\author{
Amanj Mohamed Ahmed \\ Darbandikhan Technical Institute, Sulaimani Polytechnic University / Sulaimani, \\ Kurdistan Region, Iraq \\ amanj.mohamed@spu.edu.iq \\ Muhammad Nawzad Ali \\ Darbandikhan Technical Institute, Sulaimani Polytechnic University / Sulaimani, \\ Kurdistan Region, Iraq \\ muhammad.nawzad@spu.edu.iq \\ Othman Mohammed Mahmood \\ Halabja Technical Institute, Sulaimani Polytechnic University / Sulaimani, Kurdistan \\ Region, Iraq \\ othman.mohamed@spu.edu.iq
}

\begin{abstract}
This research was carried out to determine the weight of taxation in economic development, the main purpose is to discover the level of impact of taxation on economic development or if it has any impact. Another key objective is to improve the level of understandability and find probable solutions toward issues in taxation within the Kurdistan region, as well as unveiling the Kurdistan Regional Government's taxation system in compliance with the up to date old Iraqi tax laws. KRG is barely surviving this crisis, with the increase of unemployment and poverty could taxation work as an aid to support the piles of the region. The current corruption in the government that does not use tax money efficiently and lack of transparency has been evaluated. Primary and secondary research methods were used to be able to gather information in order to reach an understanding. The primary source of data includes personal interviews and questionnaires, meanwhile, the secondary source of data includes the use of textbooks, social media, internet, and newspapers. Non-probability method of sampling was used in selecting the respondents. The study used the standard deviation, chi-square formula, and tables for the method of the examination. The results clearly illustrates that the government should commence the critical pursuit of broadening regional economy in order to improve economic growth and expansion and to become meticulous to fight with real corruption. The limitation and resources should be expanded by the government and bring taxation back to life through educational systems and social awareness.
\end{abstract}

Keywords

taxation; aid; economic development; Kurdistan Regional Government

\section{JEL Classification}

M41; O17

\section{Introduction}

\section{Background of the Study}

"Tax is a payment which the government forces the individuals, corporations, and fiduciary to pay unrelated to the goods value and provided services. Raising revenue, 
redistributing wealth, stabilizing prices and foster economic growth are the main goals of tax" (Jones et al., 2013 and Bauer et al., 2015). In general, tax victims are individuals, corporations, and fiduciary (estate). Taxation aims to enhance the governments' revenue, stabilizing economic growth through the two concepts of horizontal equity and vertical equity (Jones et al., 2013). Horizontal equity means similar circumstances should have similar tax burdens and vertical equity means circumstances of higher income should be taxed higher percentage in comparison with lower income circumstances (Armstrong et al., 2015). The most important functions of any government especially developing countries such as KRG is the provision of public and self-raised services such as electricity, water, hospital, schools, roads as well as rising the individual income of everyone within the borders, poverty alleviation to mention a few (Aikins, 2011 and Armstrong et al., 2015). For their services to be adequately provided, the government should have enough revenue to finance them. The mission of financing and controlling these huge responsibilities is one of the critical problems facing the government. Depending on the scarce resources of the government, there is an urgent demand to lift the citizens along because the imposition of tax on all taxable individuals and companies to strengthen government financial position (Aikins, 2011 and Aldy and Stavins, 2012). To this end, the government has always enacted various tax laws and reformed existing ones to stand the taste of time. They include income Tax management Act, companies income tax Decree. All these are targeting at making sure sticking to tax payment and stop supporting tax evasion and avoidance (Bauer et al., 2015 and Brand et al., 2013). For the purpose of this study, the researcher would be concerned with the impact of taxation as an aid to the economic development of the Kurdistan regional government. KRG is in compliance with the Iraqi 1982 income tax law. However, the general directorate of tax authority in KRG in 2017 announced that every company and individual is required to provide quarterly filings. Making decisions such require immediate practice and well defined set of guideline (Deloitte Touche Tohmatsu Limited, 2018). Due to, lack of information in taxation by the KRG citizens. However, tax authority requires audited financial information in order to tax the individuals or the corporations accordingly and accurately. In Kurdistan regional government, it is easy for the taxpayers to avoid tax because of the current economic crises that are facing the region. Taxation allows avoidance but tax evasion will be counted as a crime and the victim will be charged with a penalty or imprisonment (Aikins, 2011).

\section{Computing Tax}

When it comes to computing tax we have few well established concepts. Mainly for computing tax, the gross income is required in the first step (Hoffman et al., 2016). The tax models for both individual and corporation starts with gross income, sometimes for individuals we call it adjusted gross income which basically is not so different from the main concept. For the tax formula, income is needed. Also, the exclusions should be there in order to get a gross income (Larkey, 2015 and Bilau et al., 2018). Starting with gross income the tax formula changes and varies from individual to corporation. In individual tax, exemptions and includable income items are there (Bilau et al., 2018 and Tufetulov et al., 2018). But, for the corporation we have deductions and additions to income. In these two different scenarios, tax accountant and also the tax authority must focus on assessing and finding the true value (Bilau et al., 2018 and Brand et al., 2013). Also, the firms and the individuals need to have at least a brief background on tax in order not to feel cheated and to be familiar with the tax rates and the tax due amount. Sometimes, with a good tax consultant or a good tax officer inside the firm the 
amount of $\$ 1-\$ 10$ could mean nothing to the tax payer and would not even notice the impacts that this small amount of money has on the company (Zucman, 2014 and Bilau et al., 2018). In other words, let us assume that the $15 \%$ tax rates apply to the income of $\$ 100-\$ 250$, and the tax rate of $20 \%$ is applied on the income of $\$ 250-\$ 400$, if the income of an individual is $\$ 255$ they are obligated and 20\% tax rates would be imposed on them. In these cases, a good tax officer would help out the individual and deduct the income by the use of the items that can be deducted from the income, by reducing $\$ 5$ the tax rates for the individual decreases by $5 \%$ from $20 \%$ down to $15 \%$ (Tufetulov et al., 2018). Imagine if these numbers where in billions, the international companies and the huge industries might suffer from this (Larkey, 2015 and Tufetulov et al., 2018).

\section{Statement of the Problems}

The first need of any modern government is to generate enough revenue which is indeed the breath of its nostrils. Thus, taxation is by far the most significant source of revenue for the government KRG regard payment of tax as a means whereby the government raises revenue in here at the expense of their sweat. It is good to note that no tax succeeds without the taxpayer's co-operation. Here we can ask some thoughtprovoking questions such as: what makes taxation such a difficult issue? Why do people feel cheated when it comes to tax? Is the government making judicious use of taxpayer's money? In view of these questions above, this study is going to be carried out to offer a solution to them. It may not sound right to the economists and the citizens raising the suggestion of a good tax in KRG. Because, KRG is an oil country and usually the oil countries with small populations exempt the individuals and take easier roads toward taxation. Most countries with oil pay minimum amount of tax instead the people receive money annually from the government. If we account for Kuwait, individuals tax rate is zero, people do not pay taxes and also in many GDP which stands for Gross domestic product in the income method approach. People in Kuwait keep the annual return for them self by $100 \%$. Then, the question of why should KRG citizens pay tax then? Most simple answer to be given is that KRG is a very corrupted country therefore, nowadays they are suffering from an economic crises that caused by inflation and misuse of the countries resources and bad administration. In this paper, the writers oversee and focus on the tax income of the government and the economic crises impact on them.

\section{Objectives of the study}

The general objective of the study is to assess the contribution of taxes towards the growth of the Kurdistan Regional Government economy. However, the specific objective of this study is:

1. To study and show, the current taxation legislation in the region and the goal of the government.

2. To investigate and suggest, the needful actions from the tax authority and possible actions to take toward economic development.

3. To determine, why people feel cheated when it comes to tax.

4. To determine, the extent government has been using revenue generated from tax. 


\section{Value of the study}

The difference, between this research and other related research is that KRG is facing financial crises which have negatively impacted the whole region. Also, KRG as a part of Iraq which they are huge distributors of oil and listed with OPEC finding themselves stuck in an economic and political situations for many years and the struggle still continue to this day. The role of tax within every country and region if not used appropriately and well administered it will be useless. In Kurdistan, tax laws and the administrations of tax, both need to be updated and the laws need to be updated. KRG under the old laws and this current corrupted system with the help of good tax it can easily strike back up in the economy, even if it turns out hard with the accurate judgment and action the government can use the huge amount of taxes that so far has not been collected and distribute it into serving the public such as: roads, hospitals, schools, electricity, etc.

\section{Literature review}

Various theories have been conducted on tax as an aid toward economic development. They include the theories of money cycle and collection of taxes, government services, economic causes, the Indian government, tax definitions, tax collection and regulations, and Kurdistan real-estate tax.

\section{Money Circulation Theory}

For business to flourish in the country there has to be good infrastructure such as roads, telephones, electricity, etc. This infrastructure is developed by governments or through close involvement of the government (Grown and Valodia, 2010). When governments collect money from taxes it ploughs this money into development of this infrastructure and in turn promotes economic activity throughout the country (Paler, 2013). The concept of taxation is also important to businesses because governments can fund this money back into the economy in the form of loans or other funding forms (Salami, 2011 and Paler, 2013).

\section{Government services theory}

The goal of producers is to make profits by satisfying consumer demand. Open competition among producers usually results in their providing the best quality of goods or services at the lowest possible prices. The free enterprise system does not produce all the services needed by society (Salami, 2011). Some services are more efficiently provided when government agencies plan and administer them. Two good examples are national defense and state or local police protection (Salami, 2011 and Stiglitz and Rosengard, 2015). Everyone benefits from these services and the most practical way to pay for them is through taxes instead of a system of service fees. Other examples are the management of our natural resources, such as our water supply or publicly owned land, and the construction of hospitals or highways. Taxes are collected to pay for planning these services and to finance construction or maintenance (Scheve and Stasavage, 2012 and Sumner, et al., 2013). Revenue is also collected through user fees, such as at the entrances to national parks or at toll booths on highways and bridges (U.S department of treasury, 2010).

\section{Economic effects theory}

There is simply no empirical evidence or plausible economic mechanism to support the claim that cutting top tax rates spurs economic growth. (Kee, 2013 and Stiglitz and 
Rosengard, 2015) When President Bill Clinton hiked taxes, the economy boomed. When President George W. Bush slashed taxes the economy ultimately collapsed (Mills et al., 2012). It wasn't until after most of the Bush tax cuts expired during the Obama administration that the post-Great Recession recovery started to pick up steam-an ongoing recovery that, as uneven as it has been, has grown into one of the longest economic expansions in U.S. history (Kee, 2013 and Parry and Williams, 2012).

\section{Indian Tax Reform Theory}

GST the biggest tax reform in India founded on the notion of "one nation, one market, one tax" is finally here. The moment that the Indian government was waiting for a decade has finally arrived. The single biggest indirect tax regime has kicked into force, dismantling all the inner-state barriers with respect to trade (Sumner et al., 2011 and Beach, 2018). The GST rollout, with a single stroke, has converted India into a unified market of 1.3 billion citizens. Fundamentally, the \$2.4-trillion economy is attempting to transform itself by doing away with the internal tariff barriers and subsuming central, state and local taxes into a unified GST. The rollout has renewed the hope of India's fiscal reform program regaining momentum and widening the economy. Then again, there are fears of disruption, embedded in what's perceived as a rushed transition which may not assist the interests of the country (Rodden and Wibbels, 2010 and Sumner et al., 2011).

\section{Tax defining theory}

Tax is a fee charged ("levied") by a government on a product, income, or activity. According to Twomey et. al. (2011) defined tax as a compulsory payment made by individuals and firms to the government. Ola defines taxation as a compulsory financial contribution to government by individuals and corporate bodies. Government financial operations are impossible without taxation. Apart from this, taxation can be a powerful means in order to achieve the goals of social progress and the objectives of economic development (Tang et al., 2011 and Albouy, 2012). It serves as a device encourages the growth certain activities by way of giving exemptions, discourage use of certain products by way of imposing heavier charges like those sin taxes which are imposed upon tobacco products, or strengthen anemic enterprises, also by way of tax exemptions. Local industries may be protected through taxation by imposing high customs duties to foreign goods. Moreover, taxation can also be used to reduce inequities or inequalities in wealth and income by progressively higher taxes as in the case of estate and income tax. (Twomey et. al., 2011 and Tufetulov et al., 2018).

\section{KRG real-estate theory}

Parliament of Kurdistan in 2011 reissued and modified 2007 tax legislation for transformation of ownership of properties and started implementing in 2017, between the families if no more than 2,800 meter square taxes would not be imposed on them. Also, when it comes to transfer of ownership between seller and buyer taxes would be imposed only if the area of the property exceeds the 2,800 meter square (Kurdistan Parliament new rules and regulations, 2015). 


\section{Research Methodology}

\section{Research Design}

In this part, account on how this research project is being carried out is explicitly dealt with. Here, the area of study, the population, the sampling method, research instrument questionnaire, and oral interview used. The interview will consist of a number of questions designed to answer my research question. Qualitative data will be gathered from the questions where participants' responses are undefined; individuals can give their own opinions. Ethical guidelines will be used for the purpose of avoiding any ethical issues, respondents' are free to choose what to keep anonymous. An interview is used as this cost- effective and takes much less time than questionnaire the whole such number of participants, this also as mentioned will avoid ethical problems as respondents are not diverting to an uncomforted zone (Barideum, 1988; Churchill, 1976; Humphries, 2017 and Howard and Sharp, 1983).

\section{Nature of Data}

The data in this study comes from both primary and secondary source. The primary source of data deals with those data originated by the researcher as a result of studying a particular issue. The primary data for this study is made up of information generated specifically for this study. In order to have an insight into the research topic and argue as accurate as possible to the assignment. In addition, the secondary data are those existing before the need for this study was conceived but which are related to the research topic. They constitute a stepping in most research assignments for the researcher because the knowledge gained in reading and collecting materials from work done by others will fortify the researcher in this effort to generate primary data. This method of data collection was adopted because it suits the research study and equally aids to reveals the impact of taxation as an aid to economic development.

\section{Data analysis}

In this section, the researcher intends to analyze the data collected in previous part. It should be necessary to point out that the researcher used oral interview and questionnaire types of collecting data because of the advantages associated with these methods. The presentation of data as expressed below is based on the design of the questionnaire. The presentation and analysis of data which is based on the whole questionnaires are being distributed. The questionnaire indicates the effectiveness or ineffectiveness of the Kurdistan tax system based on the answer provided by the respondents.

\section{Test of Hypothesis}

We shall at this point test the hypothesis to either accept or reject them and as well determine the extent of their reliability. The acceptable of the hypothesis used in this study does not imply that the data collected was $100 \%$ reliable and error free but will only enable us know that it will not lead to disbelieve (Flick, 2015 and McCusker and Gunaydin, 2015). The probability of being in error is called the significant level of the type 1 error made and it is taken at 50\% level. Then we obtain X2 (0.001) or column is the number of independent calculations required for that row or column before the remaining unknown in that row or column can be obtained.

H1: Revenue generated from tax has a positive impact on the economic development of Kurdistan Regional Government. 
H0: Revenue generated from tax does not make any positive impact on the economic development of Kurdistan Regional Government.

Hence V $(\mathrm{r}-1)(\mathrm{C}-1)$ Where $\mathrm{R}=$ row

$\mathrm{C}=$ column

The formula of chi-square is denoted thus:

$\mathrm{X}=\Gamma(\mathrm{Oi}-\mathrm{Ei}) \quad$ Where $\mathrm{Oi}=\mathrm{Ei}=\mathrm{X}=\Gamma$

The observed frequency value the expected frequency Value of chi-square at Alpha Summation. In this test, the null hypothesis (H0) shall be accepted if X2 Oi is less than $\mathrm{X} 2$ Ei but shall be rejected then, otherwise

Hence X2 Oi = Observed hypothesis

$\mathrm{X} 2 \mathrm{Ei}=$ Expected hypothesis literature review

\section{Data Analysis and Results and Discussion}

From the data collection, analysis, and the test of the hypothesis, as it can be observed from the first question asked, most of the respondent replied with a negative response toward paying tax, along with the high rate of evasion and avoidance of tax. The high levels of tax avoidance and negative reactions are due to the low background in taxation in the region, people of Kurdistan pay taxes when the government forces them or when they have other legal works which cannot be done without the tax authority clearance. One of the major issues in the region that triggers the complexity among the people is having no information on tax, people's awareness for tax is really low and it causes continuous conflict between the taxpayers and the tax authority. Also, slows down the whole process in the daily work of the authority (Directorate of Sulaymaniyah tax authority 1,2019).

The analysis of the questionnaires showed us that the people have been unsatisfied with the government's functions. From the respondents' opinion, the researchers derived the causes of this dissatisfaction and linked it to a few reasons of corrupt officials, inefficient tax legislation, tax money not used judiciously, and bad administration of tax. From the researcher's perspective, the tax rules of 1982 are simple to implement and it is being accurately processed daily. Presence of corrupt officials, have made an effect on the relationship between the citizens and the tax authority and growing the uncertainty. The opinion of tax money not used judiciously rises due to the government's policies that have no transparency, people pay taxes in the names of services and no services have been provided to them, that is why even the tax authority does not trust the tax filings of the taxpayers.

Table 1 Probability level (alpha)

\begin{tabular}{|c|c|c|c|c|c|c|}
\hline Degree & 0.5 & 0.10 & 0.05 & 0.02 & 0.01 & 0.001 \\
\hline $\mathbf{1}$ & 0.455 & 2.706 & 3.841 & 5.412 & 6.635 & 10.827 \\
\hline $\mathbf{2}$ & 1.386 & 4.605 & 5.991 & 7.824 & 9.210 & 13.815 \\
\hline $\mathbf{3}$ & 2.366 & 6.251 & 7.815 & 9.837 & 11.345 & 16.268 \\
\hline $\mathbf{4}$ & 3.357 & 7.779 & 9.488 & 11.668 & 13.277 & 18.465 \\
\hline $\mathbf{5}$ & 4.351 & 9.236 & 11.070 & 13.388 & 15.086 & 20.517 \\
\hline & \multicolumn{5}{|c|}{ Sources: Chi-square, Math beans project. } \\
\end{tabular}


Table 1 demonstrates that the hypothesis which has been tested by the chi-square formula, the rejection of the hypothesis explain it self. The Iraqi and the Kurdish government does not depend on tax, which having that huge amount of money circulating within the region and yet still not improving the taxing source. According to the Directorate of Sulaymaniyah tax authority, the government's budget is consist of $4 \%$ of taxes, with having oil at least the government should raise the taxes up to $30 \%$. Therefore, taxes would impact the economy positively in order to obtain consistency in the economic development.

According to (Directorate of Sulaymaniyah tax authority 1, 2019), poor people pay taxes with low rates and the rich do not pay taxes at all. However, even those companies that want to pay tax, their provided financial statements will be rejected immediately by the tax authority. Because there is no trust between the government and the citizens, although, the government requires all the company's to have an internal auditor along with the external auditor to audit their financial statements to get rejected by the authority. A question may arise: then what should the companies and individuals do? Simply, the government has tax officers to reevaluate the estimated income of the companies and the individuals. As if this is not complicated enough for a society with a poor background in taxation, taxpayers are responsible to file their taxation reports in the beginning of the year. If not, the tax evaders would be fined through doubling their taxes policy and depending on the situation and the jury sometimes the cases may lead to one to five years of imprisonment.

Table 2 Chi-square Formula

\begin{tabular}{|c|c|c|c|c|}
\hline Oi & $\mathbf{E i}$ & Oi-Ei & $\begin{array}{c}\mathbf{2} \\
\text { Oi-Ei }\end{array}$ & $\begin{array}{c}\mathbf{2} \\
\text { Oi-Ei /Ei }\end{array}$ \\
\hline 15 & 11.5 & 3.5 & 12.25 & 1.065 \\
\hline 8 & 20 & -12 & 144 & 7.2 \\
\hline 27 & 18.5 & 8.5 & 72.25 & 3.91 \\
\hline 50 & 50 & 0 & & 12.171 \\
\hline \multicolumn{4}{|c|}{ Sources: Prepared and computed by the authors } \\
\hline
\end{tabular}

Cell 1: $(15+8) / 100 *(50 / 1)=11.5$ Cell $2:(8+32) / 100 *(50 / 1)=20$ Cell $3:(27+10) / 100$

$*(50 / 1)=18.5$

Hence $\mathrm{U}=(\mathrm{r}-1)(\mathrm{C}-1)$

Where $r=3$

$\mathrm{C}=2$

i.e $U=(3-1)(2-1)=2$

$\mathrm{X} 2=(0.001,2)$

13.815 from the Chi-square distribution table

Table 2 show that X2 is greater than X2 $(0.001,2)$. Hence we reject H0 (the null hypothesis) and accept the alternative hypothesis thereby concluding that revenue generated from the taxation has a positive impact on the economic development Kurdistan regional government, Iraq. 


\section{Conclusion and Recommendation}

\section{Conclusion}

Kurdistan, tax laws and also the administrations of tax, should to be updated and also the laws should be up to date. Various theories are conducted on tax as Associate a help toward an economic development. The purpose of producers is to create profits in order to satisfy the shopper's demands. Open competition below producers typically leads to providing the most effective quality of products or services at the most efficient costs. Aside from this, there is a tool that encourages the expansion bound activities by the approach of giving exemptions, discourage the use of a bound product by the approach of imposing heavier charges like those sin taxes that square measure obligatory upon tobacco product, or strengthen anemic enterprises, additionally by the approach of tax exemptions.

In our research design regard on however this research is being applied is expressly addressed. Here, the world of study, the population, the sampling methodology, analysis instrument form, and oral interviews used. On the Tabular analysis, conception took to type in tabulation and therefore the analysis taken from the finished questionnaires. Whereas assembling the questionnaires one in all the advantages that gave the investigator the advantage of asking the respondents direct queries so as to grasp the explanations behind their response. Of course, the identities area unit unbroken hidden for moral concerns. The tabular analysis could be elaborated thanks to justifying and interpret every question of the survey richly. All of this through, making a table for every question and analyze the response and therefore the reasons if doable. From the information assortment, analysis, and therefore they take a look at of the hypothesis, because it is often determined from the primary question asked, most of the respondent replied with a negative response toward paying tax, at the side of the high rate of evasion and avoiding of tax. The high levels of minimization and negative reactions square measure thanks to the low consequence in taxation within the region, people of Kurdistan pay taxes once the government forces them or once they produce other legal works that cannot be completed the tax authority clearance.

\section{Recommendation}

Based on these results and the proven factors that taxation affects the growth and has a positive impact on economic growth in Kurdistan, this research proposes the following recommendations to help raise awareness and overcome these obstacles:

1. The education system mainly need to be revised and improved, the children of today are the faces of tomorrow. With having no taxation background and lack in legal information, taxation needs to be included in the education system.

2. Taxation legislation needs to be updated. The legislation for taxation in KRG is very old and it is up to date, the last legislation was issued back in 1982.

3. Audit firms and the citizens trust. Fixing the two points stated in the above, the government or the tax authority specifically needs to work on this point toward improving the connection between them. The least they can do is to rely on the auditors when they authorize them and officially certifies them. Because, there is no one in the world that would like to pay tax, therefore, the neutrality of the auditors is needed. 


\section{References}

Aikins (2011), An examination of government internal audits' role in improving financial performance, Public Finance and Management, 11(4), 306-337.

Albouy, D. (2012), Evaluating the efficiency and equity of federal fiscal equalization. Journal of Public Economics, 96(9-10), 824-839.

Aldy, J. E., \& Stavins, R. N. (2012), The promise and problems of pricing carbon: Theory and experience, The Journal of Environment \& Development, 21(2), 152-180.

Armstrong, C.S., Blouin, J.L., Jagolinzer, A.D. \& Larcker, D.F., (2015), Corporate governance, incentives, and tax avoidance, Journal of Accounting and Economics, 60(1), 1-17.

Barideum D.M. (1988), Research Methods in Administration science, England, GradHill publishing Company.

Bauer, A.M., Fang, J., Pittman, J., Zhang, Y. \& Zhao, Y., (2015), The Importance of Aggressive Tax Planning to the Diversion of Corporate Resources: Evidence from Chinese Public Firms.

Beach, W. (2018), Why taxes affect economic growth. Accessed [2019], Retrieved from:https://www.heritage.org/taxes/report/why-taxes-affect-economic-growth

Bilau, A.A., Witt, E. \& Lill, I., (2018), Research methodology for the development of a framework for managing post-disaster housing reconstruction, Procedia engineering, 212, 598-605.

Brand, C., Anable, J., \& Tran, M. (2013), Accelerating the transformation to a low carbon passenger transport system: The role of car purchase taxes, feebates, road taxes and scrappage incentives in the UK, Transportation Research Part A: Policy and Practice, 49(2), 132-148.

Churchill G. A Jr. (1976), Marketing Research Methodological foundation, Illinois, the Dryden press.

Deloitte Touche Tohmatsu Limited (2018), International tax Iraq highlights, Retrieved from

https://www2.deloitte.com/content/dam/Deloitte/global/Documents/Tax/dttltax- iraqhighlights-2018.pdf

Flick, U. (2015), Introducing research methodology: A beginner's guide to doing a research project, US: Sage.

Grown, C., \& Valodia, I. (Eds.) (2010), Taxation and Gender Equity: A comparative analysis of direct and indirect taxes in developing and developed countries (Vol. 58), IDRC.

Hoffman, W. H., Raabe, W. A., Maloney, D. M., \& Young, J. C. (2016), South-western federal taxation (2016 ed,. Vol. Comprehensive), Cengage Learning.

Howard K and Sharp J.A. (1983), The management of student Research project, hants, Gower publishing Co.

Humphries, B., (2017), Re-thinking social research: anti-discriminatory approaches in research methodology, NJ: Taylor \& Francis.

Jones, Sally M. and Shelley C. Rhoades-Catanach (2013), Principles of Taxation for Business and Investment Planning, McGraw-Hill Irwin.

Kee, C. (2013), The Importance of Taxes to the Government and the Economy, Accessed [2019], Retrieved from: https://www.scribd.com/document/192453869/The-Importance-of-Taxes-tothe-Government-and-the- Economy.

Kurdistan Parliament, (2015), 2011' Parliament law. Retrieved from: http://www.kurdistan-parliament.org/files/articles/231111101116.pdf. 
Larkey, P. D. (2015), Evaluating public programs: The impact of general revenue sharing on municipal government, Princeton University Press.

McCusker, K. \& Gunaydin, S., (2015), Research using qualitative, quantitative or mixed methods and choice based on the research, Perfusion, 30(7), 537-542.

Mills, L. F., Nutter, S. E., \& Schwab, C. M. (2012), The effect of political sensitivity and bargaining power on taxes: Evidence from federal contractors, The Accounting Review, 88(3), 977-1005.

Paler, L. (2013), Keeping the public purse: An experiment in windfalls, taxes, and the incentives to restrain government, American Political Science Review, 107(4), 706-725.

Parry, I., \& Williams III, R. C. (2012), Moving US climate policy forward: are carbon taxes the only good alternative? Climate Change and Common Sense: Essays in Honour of Tom Schelling, 3(2), 173-202.

Rodden, J., \& Wibbels, E. (2010), Fiscal decentralization and the business cycle: An empirical study of seven federations, Economics \& Politics, 22(1), 37-67.

Salami, A. (2011), Taxation, revenue allocation and fiscal federalism in Nigeria: Issues, challenges and policy options, Economic annals, 56(189), 27-50.

Scheve, K., \& Stasavage, D. (2012), Democracy, war, and wealth: lessons from two centuries of inheritance taxation, American Political Science Review, 106(1), 81-102.

Stiglitz, J. E., \& Rosengard, J. K. (2015), Economics of the Public Sector: Fourth International Student Edition, US: WW Norton \& Company.

Sumner, J., Bird, L., \& Dobos, H. (2011), Carbon taxes: a review of experience and policy design considerations, Climate Policy, 11(2), 922-943.

Tang, B. S., Wong, S. W., \& Liu, S. C. (2011), Institutions, property taxation and local government finance in China, Urban Studies, 48(5), 847-875.

Tufetulov, A.M., Nugaye, F.S. \& Zayats, A.S., (2018), Pricing Agreement and its Importance for the Tax Control of Transactions between Related Parties, HELIX, 8(1), 2328-2332.

Twomey, David P. and Marianne Moody Jennings (2011), Business Law and the Legal Environment, South-western.

U.S Department of the Treasury (2010), Economics of Taxation, Accessed [2019], Retrieved from: https://www.treasury.gov/resourcecenter/faqs/Taxes/Pages/economics.aspx.

Zucman, G. (2014), Taxing across borders: Tracking personal wealth and corporate profits, Journal of Economic Perspectives, 28(4), 121-48. 